\title{
Facies characteristics of the basal part of the Talchir Formation, Talchir Basin, India - depositional history revisited
}

\author{
Prabir Dasgupta* and Rishiraj Sahoo \\ Department of Geology, Presidency College, 86/1 College Street, Kolkata 700 073, India. \\ *e-mail: pdggeopc@cal3.vsnl.net.in
}

\begin{abstract}
The lowest unit of the Talchir Formation of Talchir Basin, Orissa, was described by pioneer workers as the 'basal boulder bed'. In an attempt to explain the co-existence of gravel and clay, materials of contrasting hydraulic properties, a probable situation resembling the effects of the action of ground-ice enabled boulders to be carried down by sluggish currents resulting in an intermixture of large boulders and fine mud was conceived. Misinterpretation of this conclusion led to a general tendency to describe the 'basal boulder bed' as 'glacial tillite'. However, the unit described as 'basal boulder bed' is actually represented by a matrix rich conglomerate with pockets of normally graded silty clay. The present study reveals that the depositional imprints preserved in this part of the sedimentary succession indicate emplacement of successive debris flows generated through remobilization of pre-existing unconsolidated sediments. Small pockets of fine-grained turbidites presumably deposited from the entrained turbidity currents associated with the debris flows suggest the composite character of the debris flow deposit.
\end{abstract}

\section{Introduction}

The onset of Gondwana sedimentation marked the end of a long period of non-deposition that prevailed in peninsular India from late Proterozoic to upper Paleozoic, and hence is considered as one of the significant geological events of this part of the globe. The Talchir Formation, being the lowest unit of this upper Paleozoic sedimentary succession, thus deserves special attention for a proper understanding of the Paleozoic geological history of the Indian subcontinent.

Blanford et al (1856) were first to describe the Gondwana succession of the Talchir Basin, Orissa and designated its lower part as the Talchir Group of rocks. Since then its lithological equivalents encountered at the lowest levels of all Gondwana basin-fills in India have been identified as Talchir deposits with the status of 'formation' in present day lithostratigraphic classification (Sastry et al
1977). The Talchir Formation of different Gondwana basins has been widely studied by generations of workers and a wide spectrum of views regarding the depositional setting have been expressed in the literature. A literature survey reveals that the pioneering contribution of Blanford et al (1856) is often cited in favour of the glacial origin of the lower part of Talchir succession (Sastry et al 1977). The Talchir Formation of the Talchir Basin was subsequently classified into three informal units (Pandya 1990; Maejima et al 1999). A critical review of the classification described by Maejima et al $(1999$, p. 105) reveals that in the original proposal Pandya (1990) either classified the Talchir succession excluding the basal glacial tillite or the same unit (Facies A, Pandya 1990) was interpreted as of fluvial origin. However, according to Maejima et al (1999), the lowest unit of that proposed classification starts with glacial tillite, which gradually passes upward into fluvial sediments.

Keywords. Gondwana sedimentation; Talchir Formation; Talchir Basin; debris flow; entrained turbidity current. 
The other two units were attributed to lacustrine regime. Maejima et al (1999) did not furnish any descriptive parameter for the 'glacial tillite' and cited the work of Blanford et al (1856) in support of their interpretation. Maejima et al (2004) described the lowermost part of the Talchir succession as of glacial origin. Surprisingly, no unequivocal evidence in favour of such an interpretation was furnished. Marked mismatch in thickness between the lithologs (Maejima et al 2004, figures 3, 4 and 5) and the radical difference between the general successions illustrated by figure 4 in Maejima et al (1999) and figure 3 in Maejima et al (2004) made the whole thing more confusing. In support of the interpretation it was reiterated (Maejima et al 2004, p. 341) that the idea of glacial origin for these sediments was introduced by Blanford et al (1856). But a careful analysis of the inferences drawn by Blanford et al (1856) reveals a different picture.

Blanford et al (1856) made an attempt to explain the co-existence of boulder and fine mud within the 'basal boulder bed' and analyzed different possibilities (Blanford et al 1856, p. 49-56) for the simultaneous deposition of the materials of contrasting hydraulic properties. Finally, a probable situation very similar to the effects of the action of ground-ice that enabled boulders to be carried down by sluggish currents and produced an intermixture of large boulders and fine mud was postulated (Blanford et al 1856, p. 49). Simultaneously the possibility of transport by true glaciers was strongly ruled out (Blanford et al 1856, p. 50). Hence, the idea of a pure glacial origin of the lower part of Talchir succession of Talchir Basin and identification of the 'basal boulder bed' described by Blanford et al (1856) as tillite do not have any strong foundation, and the sediments deserve reexamination for the decipherment of the actual depositional mechanisms involved. This is of great significance to work out the actual time relation between Permo-Carboniferous glaciation and origin of intracratonic Gondwana basins, two important events in Palaeozoic history of peninsular India. The present work aims at the detailed study of the so-called 'basal boulder bed' with a view to expound the depositional history. This understanding has an important bearing on the reconstruction of the tectonosedimentary history of the initial phase of Gondwana sedimentation in peninsular India.

\section{Geological setting}

The Talchir Basin is the eastern-most member of the Gondwana basins of Mahanadi Valley (figure 1). It is a NW-SE trending elongated basin amidst Archean rocks and lies between latitudes $20^{\circ} 45^{\prime} \mathrm{N}$ and $21^{\circ} 20^{\prime} \mathrm{N}$ and longitudes $84^{\circ} 32^{\prime} \mathrm{E}$ and $85^{\circ} 32^{\prime} \mathrm{E}$. In this basin, the lower Gondwana succession, overlying the Archean basement, starts with the Talchir Formation (lower Permian). This is followed successively upward by the Karharbari, Barakar and Kamthi formations (Blanford et al 1856; Raja Rao 1982; Pandya 1990; Maejima et al 1999) (figure 1). The 'basal boulder bed' (as described by Blanford et al 1856) under study constitutes the lowest part of the Talchir Formation and is exposed along the Nandir Jhor and its tributary streams in the south-southeastern part and partly in the Tikra river in the northern part of the basin (figure 1).

\section{The 'basal boulder bed'}

\subsection{Description}

The lower part of the Talchir Formation is mainly represented by a matrix-rich conglomerate-shale succession with relatively minor amount of sandstone. As mentioned earlier, Blanford et al (1856) described the lowest unit of this succession as the 'basal boulder bed', which is best exposed along the Poipani (a tributary of Nandir Jhor) section (figure 1). The 'basal boulder bed', resting on the Archean basement gneiss, attains a thickness of about 9 meters and is conformably overlain by 16 meters of thick gray shale with a sharp contact. The 'basal boulder bed' is represented by matrixrich conglomerate (matrix content is about $60-70 \%$ by volume of the whole rock) with very poorly sorted gravel fraction randomly distributed within clay-rich matrix material (figure 2A). Gravel fraction ranges in size from large boulder to granule, with modal value around coarse pebble to fine cobble. The largest boulder measures $67 \mathrm{~cm}$ in diameter. Boulders are sub-angular (in the lower part) to well rounded (in the middle and the upper part) and the other members of the gravel fraction are sub-rounded to rounded. Fragments of amphibole gneiss and quartzite constitute the main bulk of the gravel population. The presence of upright cobbles and boulders characterizes this conglomerate. In the lower part, occasionally, the elongate boulders show an alignment apparently subparallel to the depositional surface (figure $2 \mathrm{~A}$ ). The most significant feature is the presence of a lenticular pocket (about 1 meter thick and 15 meters wide) of graded silty clay within this matrix-rich conglomerate (figure 2A, B). The basal contact of this pocket is gradational with the conglomerate while it shows truncation relation with the same conglomerate at the top. The silty clay layers gradually pinches out towards north while towards south the bedding 


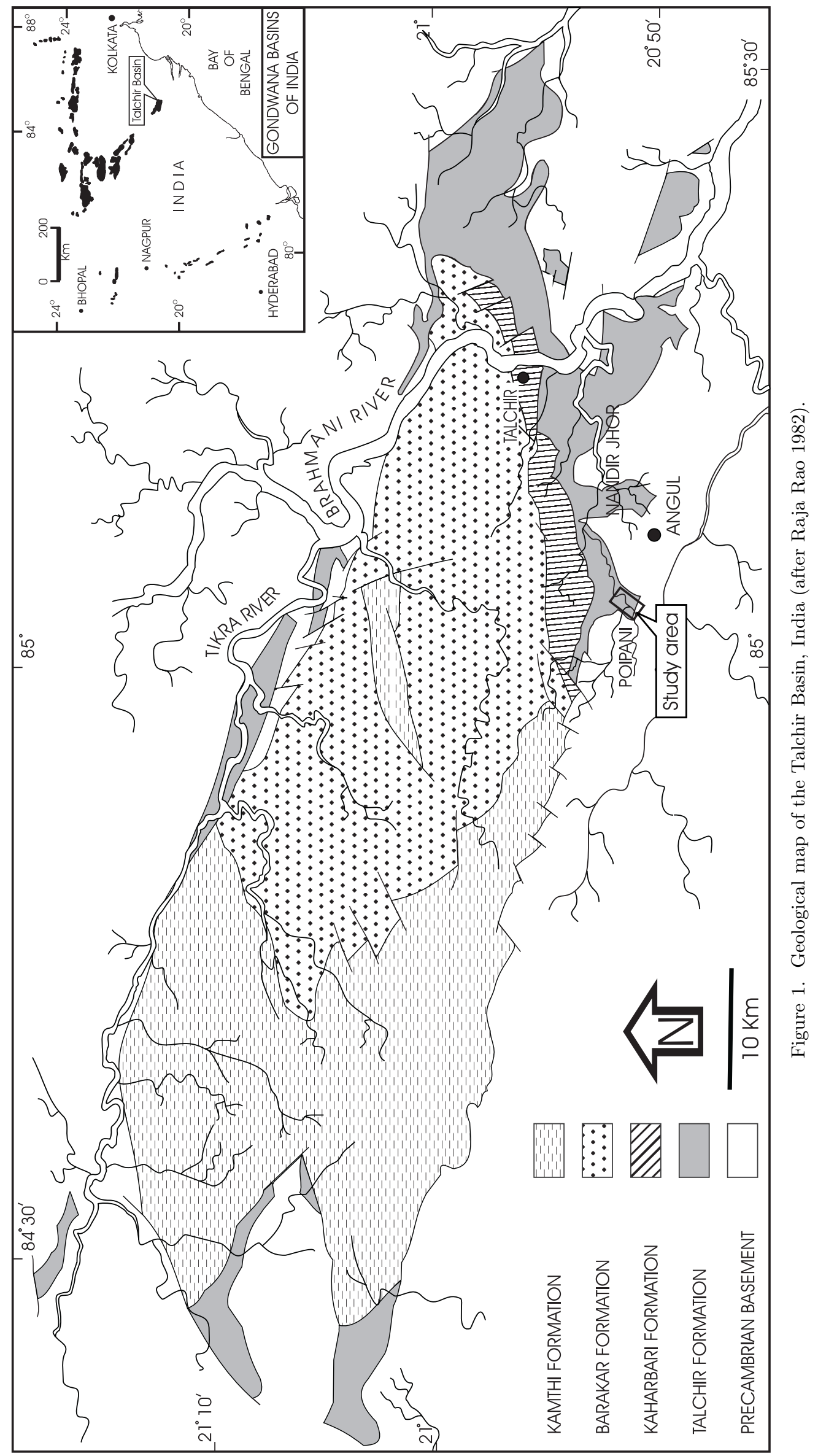



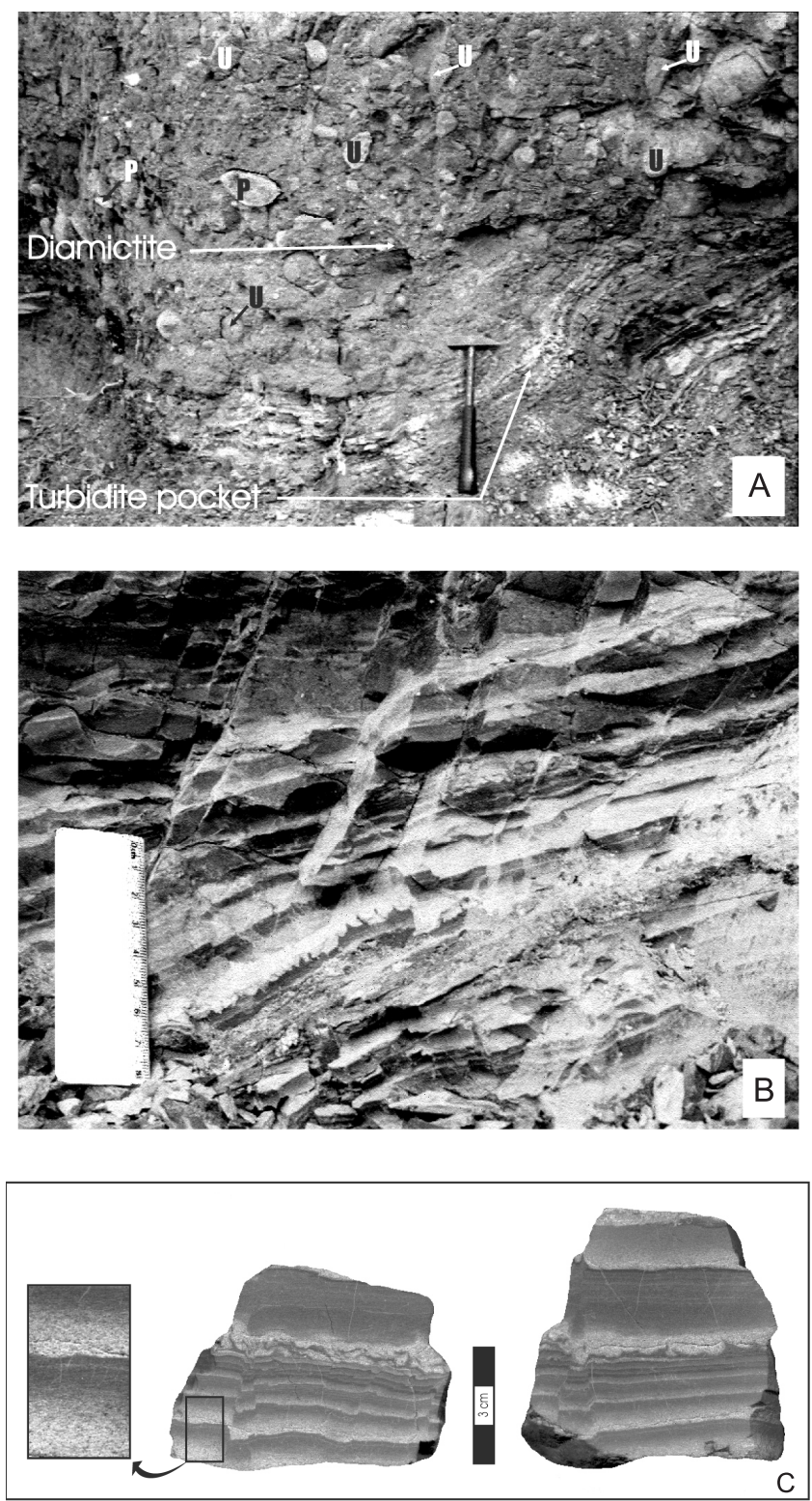

Figure 2. (A) Matrix-rich conglomerate with pockets of graded silty clay. Variation in the orientation of the long axes of the gravels with reference to the depositional surface is noteworthy. Some members of the gravel fraction are in upright position (marked ' $U$ ') while some others are parallel to the depositional surface (marked ' $\mathrm{P}$ '), bending of the graded silty clay due to the shearing effect of the over-riding conglomerate is apparent (the hammer is $32 \mathrm{~cm}$ long). (B) Close-up view of the graded silty clay. The arrow shows load structure at the clay-silt interface (the scale is $8 \mathrm{~cm}$ long). (C) Bitmap images of graded silty clay. The rectangular area is enlarged to show the graded character. The two specimens show variation in the degree of penecontemporaneous deformation at the silt-clay interface.

planes suffered an upward bending and finally truncated against the host conglomerate (figure 2A). In the lower part of the unit, the graded layers are about 10 to $15 \mathrm{~mm}$ thick and are characteristically silt-rich. The thickness of these graded-layers gradually increases upward and attains a maximum value of about $4 \mathrm{~cm}$ with simultaneous increase in the proportion of clay. In the lower part, the interface between the silt-rich and the clay-rich parts of successive layers suffered penecontemporaneous deformation, as is evident from the welldeveloped load structures and layer contortions (figure 2C).

\subsection{Interpretation}

Absence of any unequivocal signature of glacial origin and dominance of rounded gravel within this matrix-rich conglomerate go against the interpretation of glacial tillite. Remobilization of the preexisting sediments in bringing about the present conglomerate appears more plausible. The overall massive character and chaotic distribution of gravel fraction floating within clay-rich matrix indicate deposition of this conglomerate possibly from cohesive debris flow. Presence of upright cobbles and boulders are suggestive of the thixotropic nature of the flow.

Abrupt freezing of a single debris flow is difficult to be conceived as the mechanism to bring a thick deposit into existence. The thick debris flow deposits are generally considered as the product of deposition from incremental aggradation of a number of surges (Davies 1986, 1990; Major 1997; Sohn et al 1999). Deposit of the earlier surge does not normally consolidate before emplacement of the later one and the single massive layer results through amalgamation of successive surges. Apparent alignment of a few elongate clasts parallel to the depositional surface can be attributed to the high rate of laminar shear straining of individual surges (Fisher 1971; Enos 1977) associated with spreading or extensional deformation during emplacement and subsequent smearing by later surges before the deposit of earlier surges consolidated. The cumulative deposit thickness thus greatly exceeded the average flow thickness.

In the lensoid pocket, embedded within the conglomerate, distribution type normal grading observed within the silty-clay layers indicates inflow differentiation of grains, likely to take place within turbidity currents as demonstrated by Middleton (1966a, 1966b, 1967). Appearance of load cast and contorted layers suggests rapid sedimentation before minimum compaction of the clay material of the earlier deposit. So influx of turbulent surges in quick succession can be inferred. Gradual decrease in the proportion of silt and simultaneous increase in clay content towards the top of the unit further suggests gradual decrease in the energy condition of successive turbulent surges. The turbidity currents were probably generated at the interface between the debris flow 


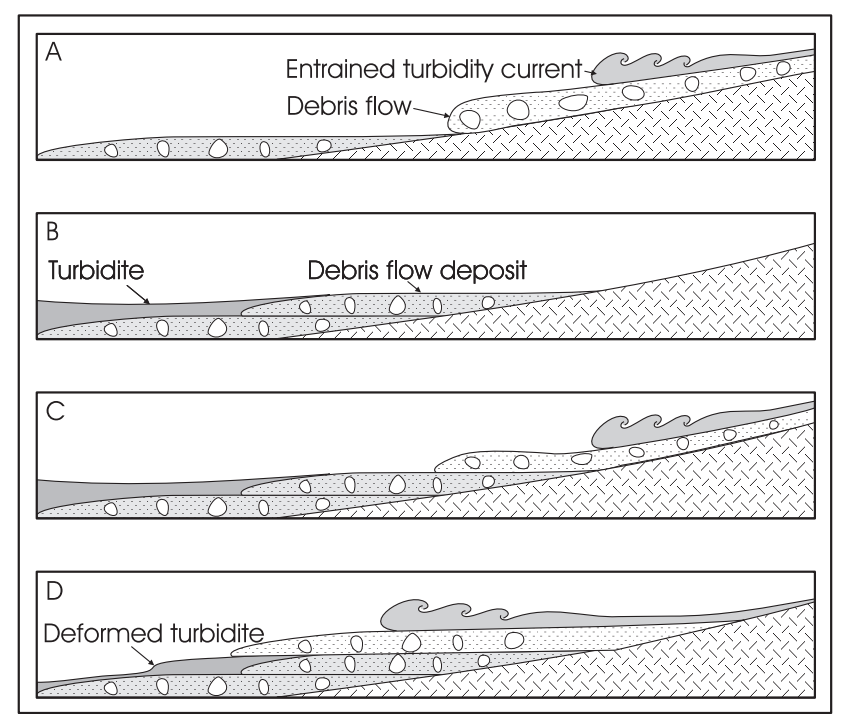

Figure 3. Schematic diagram showing the inferred stages of development of the pockets of graded silty clay within conglomerate. (A) and (B) depict gradual progression of a debris flow with entrained turbidity current. (C) The next influx of debris flow set in after deposition from the earlier phase of debris flow and the associated turbidity current. (D) During emplacement of the debris flow over the earlier fine-grained turbidites, the latter underwent ductile deformation due to the shearing effect of the denser debris flow.

and the ambient water due to frictional drag during emplacement of the former (entrained turbidity current) (Nemec 1990; Dasgupta 2003). The experimental observations of Felix and Peakall (2006) also go in favour of such processes of generation of turbidity currents from debris flow. After the deposition from the debris flow, the entrained turbidity current proceeded further and deposition took place beyond the snout of the debris flow deposit (figure 3). The upper part of the turbidite deposit was dragged during emplacement of the next debris flow, which caused bending and finally truncation of the silty clay layers due to shearing. Hence, presence of the lensoid turbidite pocket of graded silty clay within the matrix-rich conglomerate goes in favour of the origin of host sediments through amalgamation of deposits from successive debris flow surges. Mulder and Alexander (2001) described a similar deposit from northwest Mediterranean Sea as spillover turbidite deposit. Talling et al (2004) described co-genetic debrite-turbidite successions from three widespread successions of variable age: Miocene Marnoso Arenacea Formation in the Italian Apenines, Silurian Aberystwyth Grits in Wales, and Quaternary deposits of the Agadir Basin, offshore Morocco. Detailed study of the anatomy of turbidites and linked debrites from the Marnoso Arenacea Formation, northern Apenines, Italy led Amy and Talling (2006) to conclude that a single subaqueous flow event can comprise multiple flow phases and deposit a bed with complex lateral changes between mud-rich and mud-poor sandstone.

\section{Discussion}

The depositional imprints preserved in the lower part of the Talchir Formation of the Talchir Basin indicate that within this basin the Gondwana sedimentation was initiated through emplacement of successive debris flows. Remobilization of the pre-existing unconsolidated sediments possibly led to the deposition of the debris flow conglomerate. Small pockets of fine-grained turbidites presumably deposited from the entrained turbidity currents associated with the debris flows suggest the composite character of the debris flow deposit.

Deposition of the lower part of the Talchir Formation through resedimentation processes has also been inferred from other Gondwana basins of peninsular India. After studying the rocks of Talchir Formation in the Damodar valley basins, Fox (1930) expressed serious reservations regarding the identification of these sediments as purely glacial deposits. Fox (1930) emphasized that although the general character of the gravel fraction indicates ultimate derivation by some moving ice sheet from a distal source, the character of the deposits lacks evidence for a primary glacial origin, and instead shows indications of reworking. Ganju and Srivastava (1959) and Niyogi (1961) also advocated the deposition of the Talchir sediments through reworking of glacial moraines. Dasgupta (2006) made a detailed study of the Talchir succession of the Jharia Basin of Damodar Valley and established a time relation between the PermoCarboniferous glaciation, formation of Gondwana basins and the onset of Gondwana sedimentation, and evidences from other basins substantiated the view. This analysis also indicates a post-glaciation resedimentation process involved in the initiation of the Gondwana sedimentation. In the present context also remobilization of some pre-existing glacial debris in generation of the debris flows cannot be ruled out.

Hence the depositional mechanisms postulated by Blanford et al (1856) appear to be very close to the inferred situation. Their idea of the probable situation resembling the effects of the action of ground-ice that enabled boulders to be carried down by sluggish currents and produced an intermixture of large boulders and fine mud (Blanford et al 1856, p. 49) can be regarded as one of the pioneering contributions in the concept of debris flow. 


\section{Acknowledgements}

This work has been carried out with the financial assistance from the University Grants Commission, India. Authors express their gratitude to Dr. Rajat Mazumder of the University of Munich, Germany and to the anonymous reviewer for their critical review and valuable suggestions.

\section{References}

Amy L A and Talling P J 2006 Anatomy of turbidites and linked debrites based on long distance $(120 \times 30 \mathrm{~km})$ bed correlation, Marnoso Arenacea Formation, Northern Apenines, Italy; Sedimentology $\mathbf{5 3}$ $161-212$.

Blanford W T, Blanford H F and Theobald W 1856 On the geological structure and relations of the Talcheer Coalfield in the district of Cuttack; Geol. Surv. India Memoir 1 1-98.

Dasgupta P 2003 Sediment gravity flow - the conceptual problems; Earth-Sci. Rev. 62 265-281.

Dasgupta P 2006 Facies characteristics of Talchir Formation, Jharia Basin, India: implications for initiation of Gondwana sedimentation; Sedim. Geol. 185 59-78.

Davies T R H 1986 Large debris flows: a macroviscous phenomenon; Acta Mechanica 63 161-178.

Davies T R H 1990 Debris-flow surges - experimental simulation; J. Hydrol. 29 18-46.

Enos P 1977 Flow regimes in debris flow; Sedimentology 24 133-142.

Felix M and Peakall J 2006 Transformation of debris flows into turbidity currents: mechanisms inferred from laboratory experiments; Sedimentology 53 107-124.

Fisher R V 1971 Features of coarse-grained, highconcentration fluids and their deposits; J. Sedim. Petrol. 41 916-927.

Fox C S 1930 The Jharia Coalfield; Geol. Surv. India Memoir 56255.

Ganju P N and Srivastava V K 1959 Pebble fabric analysis of the Talchir Boulder Bed in the Jharia Coalfield, Bihar; J. Geol. Soc. India 1 105-115.
Maejima W, Nakajo T, Das R, Pandya K L and Hayashi M 1999 Turbidite sedimentation in the Late Paleozoic Talchir Gondwana Basin, Orissa, India; J. Geosciences, Osaka University 42 103-114.

Maejima W, Das R, Pandya K L and Hayashi M 2004 Deglacial control on sedimentation and basin evolution of Permo-Carboniferous Talchir Formation, Talchir Gondwana basin, Orissa, India; Gondwana Res. 7 339-352.

Major J J 1997 Depositional processes in large-scale debrisflow experiments; J. Geology 105 345-366.

Middleton G V 1966a Experiments on density and turbidity currents. I. Motion of the head; Can. J. Earth Sci. 3 523-546.

Middleton G V 1966b Experiments on density and turbidity currents. II. Uniform flow of density currents; Can. J. Earth Sci. 3 627-637.

Middleton G V 1967 Experiments on density and turbidity currents. III. Deposition of sediment; Can. J. Earth Sci. 4 475-505.

Mulder T and Alexander J 2001 The physical character of subaqueous sedimentary density flows and their deposits; Sedimentology 48 269-299.

Nemec W 1990 Aspects of sediment movement on steep delta slopes; In: Coarse-grained deltas (eds) Colella A and Prior D B, Spec. Publ. Int. Assoc. Sed. 10 29-73.

Niyogi D 1961 Pattern of Talchir sedimentation in Burhai Gondwana Basin; J. Sedim. Petrol. 31 63-71.

Pandya K L 1990 Lithofacies and environments of deposition of a part of Talchir Group, Talchir Basin, Orissa; J. Geol. Soc. India 36 175-186.

Raja Rao C S 1982 Coal resources of Tamil Nadu, Andhra Pradesh, Orissa and Maharashtra; Bull. Geol. Surv. India A45 103.

Sastry M V A, Acharyya S K, Shah S C, Satsangi P P, Ghosh S C, Raha P K, Singh G and Ghosh R N (eds) 1977 Stratigraphic lexicon of Gondwana Formations of India; Misc. Publ. Geol. Surv. India 36170.

Sohn Y K, Rhee C W and Kim B C 1999 Debris flow and hyperconcentrated flood-flow deposits in an alluvial fan, northwestern part of Cretaceous Yongdong Basin, central Korea; J. Geology 107 111-132.

Talling P J, Amy L A, Wynn R B, Peakall J and Robinson M 2004 Beds comprising debrite sandwiched within co-genetic turbidite: origin and widespread occurrence in distal depositional environments; Sedimentology 51 163-194. 